\title{
Perspectives on Online Undergraduate Research
}

\author{
Arriane Pirhalla \\ College of Liberal Arts \& Sciences
}

Faculty Mentor: Crystal Marull, Department of Spanish \& Portuguese Studies

\begin{abstract}
With the rise of online education surrounding the current global situation, facilitating engaging, communicative, and interesting online courses and research has become increasingly important. This study surveyed various undergraduate students at the University of Florida $(n=114)$, gathering perspectives on their awareness of, interest in, and opinions on online undergraduate research and courses. This study found that a majority of students $(74.58 \%, n=88)$ surveyed were not aware of online research programs like the University Scholars Program, despite the majority $(71.67 \%, \mathrm{n}=81)$ indicating they were at least moderately interested in the program. Students also overwhelmingly rated research as being very or extremely important, especially for post-graduate work or school. This paper discusses the implications of relationships between these responses and touches on suggested future research.
\end{abstract}

Keywords: online education, undergraduate research, STEM

\section{Perspectives on Online Undergraduate Research}

As the internet becomes a more vital and accessible part of everyday life, the potential to utilize it for advanced and inclusive learning increases. In 2007, almost 3.5 million students were taking a minimum of one online course (Allen \& Seaman, 2007). Ten years later, there were a staggering 6.6 million students enrolled in distance education (NCES, 2018), a near double of the 2007 figure, and one that has recently exploded due to the COVID-19 pandemic and the pivot to online education for all higher education. This massive increase in online learning is supported by evidence that online learning facilitates the same degree of education as face-to-face classes; that is, there is "no significant difference" between the content learned and scores of online vs. face-to-face students (Swan, 2003, p. 3). However, this paper proposes that there are significant differences in participation and awareness of research facilitation.

In a 2010 study of undergraduate research opportunities offered by UCLA faculty, only $61 \%$ of faculty reported including online students in their research (Eagan et al. 2010). Participation in 
undergraduate research is increasing in tandem with undergraduates' interest in research, and also contributes to STEM career retention (Eagan et al. 2010, Russel et al. 2007) This data suggests that undergraduate research opportunities are increasing in face-to-face programs to match increasing interest. Meanwhile, online learning lacks access to research opportunities despite a rapidly growing online population and data showing that undergraduate research facilitates increased diversity, increased work knowledge and critical thinking, self-confidence, networking opportunities and improved career or academic opportunities (Hernandez et al. 2018; Lopatto 2007; Volz 2021).

When considering the data on why online students drop out, do not participate in, or are dissatisfied with any program, some of the leading conclusions are lack of social integration including informal, academic and formal social systems (i.e. faculty interactions, extracurricular activities/research and peer groups), decreased motivation linked to the nature of online learning, and a lack of student-to-student collaborations and instructor-student interactions (Croxton, 2014; Herbert, 2005; Yukselturk \& Inan, 2006). Women, and women of color in particular, were reportedly more likely to feel less involved with faculty, and such statistics are markedly more drastic than the previously cited studies (Espinosa, 2011; Veiyra et al., 2011).

Broadly, this study aimed to discern the interest level and knowledge of undergraduate research opportunities, explore STEM retention, and discuss perspectives of online courses and online research opportunities. Undergraduate research opportunities can be a pathway to success, and with $62.5 \%(n=324)$ of UF online students being interested in graduate research, it is extremely important to survey and meet the goals of online undergraduates with respect to opportunity (UF Online Student Experience Survey, 2019).

\section{Methods}

This survey was designed using an online-based Qualtrics (Qualtrics, Provo, UT, version October 2020) survey platform to collect data from University of Florida students. Basic demographic and academic information were collected, and opinions were collected through predefined options that were situated on six-point Likert Scales, where 1 represented negative opinions and 5 represented positive opinions, with options for neither, when applicable, and additional comments. While the study was aimed at online undergraduate students, all affiliates of the University of Florida were encouraged to participate. Questions were designed to quantify 
student interest, knowledge of, and opinions on research and online courses. 122 participants responded (114 undergrad, 1 grad, 4 faculty/other), though not every respondent answered every question; some questions were conditioned on previous responses, and respondents could skip any question they did not wish to answer.

The survey was sectioned into demographic information, university affiliation, knowledge and experience on research, and then experiences and opinions on online courses. Demographic information collected included age, gender, and race. Affiliation included current university role affiliation, enrollment status, course modality (including options for students taking multiple different course formats), familiarity with online learning, and information about major degree programs, if applicable.

Interest in research opportunities and opinions on importance were quantified at a six-point Likert scale where 1 indicated not interested and 5 indicated extremely interested. Awareness of research programs were binary yes or no questions. Respondents were asked if they felt they received the same level of communication as their peers, with the question being worded dependent on their modality: online only respondents were asked if they felt they received the same level of communication as their in-person peers, and vice versa for in-person respondents.

Statements regarding online courses were formatted in a matrix with another six-point Likert scale where 1 indicated not interested and 5 indicated extremely interested, with 6 being neither agree nor disagree. Respondents were asked to rate their agreement with statements relating to preconceptions about online students, online degrees, and the resources provided to online students.

A section for optional comments was provided at the end, for information respondents felt may be useful or constructive to the research. All information was collected and stored anonymously. The survey was disseminated to students in numerous online courses, through official email channels to which the researchers had access. Participation was incentivized by offering a \$20 Amazon gift card to every 25th participant (i.e., 25th participant, 50th participant, etc.) Both recruitment and the survey followed guidelines set forth by the Institutional Review Board (IRB). 


\section{Results}

Respondents were asked to provide various demographic information: age, gender, race, affiliation and major. A large majority of respondents $(95.8 \%, \mathrm{n}=114)$ indicated they were undergraduate students. Most respondents were also white $(78.15 \%, \mathrm{n}=93)$ and female $(76.47 \%$, $\mathrm{n}=91$ ). Respondents' demographic and academic information is further described in Table 1 .

Table 1. Demographic and academic information on respondents.

\begin{tabular}{lcccc}
\hline \multicolumn{1}{c}{ Individual-Level Variables } & $\mathrm{N}$ & Percent & Mean & Range \\
\hline Age & 117 & & 25.83 & $18-70$ \\
Gender & 119 & & & \\
Male & 23 & 19.33 & & \\
Female & 91 & 76.47 & & \\
Other & 5 & 4.2 & \\
Race & 119 & & \\
White & 93 & 78.15 & \\
Black/African American & 5 & 4.2 & \\
American Indian / Alaska Native & 0 & 0 & \\
Asian & 14 & 11.76 & \\
Native Hawaiian / Pacific Islander & 1 & 0.84 & \\
Other & 6 & 5.04 & \\
Affiliation & 119 & & \\
Undergraduate & 114 & 95.8 & \\
Graduate & 1 & 0.84 & \\
Faculty & 4 & 3.36 & \\
Major & 116 & & \\
STEM & 64 & 55.17 & \\
non-STEM & 52 & 44.83 & \\
Modality & 150 & & \\
Online & 106 & 70.67 & \\
Hybrid & 29 & 19.33 & \\
Face to Face & 15 & 10.0 & \\
Online Experience & 02 & 69.49 & \\
Extremely Familiar & 20 & 16.95 & \\
Very Familiar & 14 & 11.86 & \\
Moderately Familiar & 2 & 1.69 & \\
Slightly Familiar & 0 & \\
Not Familiar & & & \\
\hline
\end{tabular}


Of the 11 respondents that indicated they are not currently a STEM major and provided reasoning, $1.92 \%(\mathrm{n}=1)$ said they had previously been enrolled in a STEM field and completed a degree, $21.15 \%(n=11)$ said they had previously been enrolled in a STEM field but did not complete their degree or switched majors, and 76.92\% $(n=40)$ had never been enrolled in a STEM field. The top three reasons for not completing or switching majors from STEM were stated, in order by majority, to be 1 . Career Goals changed $(23.08 \%, n=6), 2$. Academic Stress $(19.23 \%, n=5)$, and 3. Lack of Interest $(15.38 \%, n=4)$. Table 2 depicts the primary reasons former STEM majors did not complete their degree.

Table 2. Primary reasons former STEM majors did not complete their degree.

\begin{tabular}{lcc}
\hline \multicolumn{1}{c}{ Reasoning } & $\mathrm{n}$ & Percentage \\
\hline Financial Reasons & 3 & 11.54 \\
Family or other personal issues & 2 & 7.69 \\
Academic Stress & 5 & 19.23 \\
Lack of interest & 4 & 15.38 \\
Lack of support & 3 & 11.54 \\
Career goals changed & 6 & 23.08 \\
Major was not what I expected & 1 & 3.85 \\
It was unsatisfying & 1 & 3.85 \\
Other (medical reasons) & 1 & 3.85 \\
Total Respondents & $\mathrm{N}=11$ & \\
\hline
\end{tabular}

Note. Only respondents who indicated that they were previously enrolled as a STEM major at some point could respond. Respondents were asked to select all that applied.

\section{Responses on Research}

Responses regarding perceptions of communication in online courses versus face-to-face courses were fairly distributed through all ranges except for the range of "definitely" asserting that online courses receive the same level of communication as face-to-face ones, as seen in Table 3. This data was calculated by looking at the number of respondents who were taking some combination of in person and online courses, and then surveying their opinion on the discrepancies between communication, if any. They were asked to rate their agreement to the following statement: "Do you feel that you get the same level of communication and access to information about academic opportunities for your online courses as your in-person ones." 
Table 3. Modality and opinion of receiving the same level of communication for online courses versus face-to-face ones.

\begin{tabular}{lccccc}
\hline \multicolumn{1}{c}{ Modality } & $\begin{array}{c}\text { Definitely } \\
\text { Yes }\end{array}$ & $\begin{array}{c}\text { Probably } \\
\text { Yes }\end{array}$ & $\begin{array}{c}\text { Might or } \\
\text { Might Not }\end{array}$ & $\begin{array}{c}\text { Probably } \\
\text { Not }\end{array}$ & $\begin{array}{c}\text { Definitely } \\
\text { Not }\end{array}$ \\
\hline Online & 1 & 4 & 4 & 4 & 4 \\
Hybrid & 1 & 4 & 4 & 4 & 4 \\
Face to Face & 0 & 3 & 4 & 4 & 3 \\
Total responses & $\mathrm{N}=48$ & & & & \\
\hline
\end{tabular}

Note. Only respondents who indicated that they are simultaneously taking online and faceto-face courses or hybrid courses were enabled to respond.

Nearly all participants $(97.41 \% ; \mathrm{n}=108)$ indicated that research was moderately $(31.03 \%$, $n=34)$, very $(34.48 \%, n=39)$ and extremely important $(31.9 \%, n=35)$ in terms of academic success. Additionally, interest in participation of research was related to how highly respondents rated the importance of research, as seen in Table 4. Respondents who were extremely interested in undergraduate research $(73.91 \% ; n=17)$ also found it to be extremely important. The only respondent who found research to be not important at all was simultaneously not interested in it at all. The majority of respondents were at least moderately interested and found research to be moderately important. Only $1.72 \%(n=2)$ responded that research was only slightly important, and $0.86 \%(n=1)$ responded that research was not at all important to academic success.

Table 4. Interest in research and how important the respondent considers research to be in terms of academic success, $N=111$.

\begin{tabular}{lccccc}
\hline \multicolumn{1}{c}{ Likert Value } & $\begin{array}{c}\text { Extremely } \\
\text { Important }\end{array}$ & $\begin{array}{c}\text { Very } \\
\text { Important }\end{array}$ & $\begin{array}{c}\text { Moderately } \\
\text { Important }\end{array}$ & $\begin{array}{c}\text { Slightly } \\
\text { Important }\end{array}$ & $\begin{array}{c}\text { Not } \\
\text { Important at All }\end{array}$ \\
\hline Extremely Interested & 17 & 3 & 3 & 0 & 0 \\
Very Interested & 7 & 8 & 5 & 0 & 0 \\
Moderately Interested & 7 & 16 & 13 & 1 & 0 \\
Slightly Interested & 1 & 8 & 10 & 0 & 0 \\
Not Interested at All & 2 & 4 & 4 & 1 & 1 \\
\hline
\end{tabular}

Note. Only respondents who indicated that they are simultaneously taking online and face-to-face courses or hybrid courses were enabled to respond.

Another perspective considered in this survey was if students were aware of research projects and opportunities, through the University Scholars Program (USP) or otherwise. An overwhelming number of respondents, $74.58 \%(n=87)$ were not aware of the USP program. 
However, $46.9 \%(n=52)$ reported being aware of other undergraduate research programs.

Awareness of USP or other research programs were not found to be related to race or gender.

\section{Opinions on Modality}

Respondents also reported their perspectives on online courses. $79.82 \%(n=91)$ of respondents reported that they "[did] not agree at all" to the statement that "online courses are less demanding." However, responses were split when asked whether they agreed with the statement that online courses were "harder than in person courses", as shown in Table 5. The majority $(79.83 \%, \mathrm{n}=91)$ of respondents moderately, very or definitely agree that research experience is important to graduate school, and again a majority $(78.07 \%, \mathrm{n}=89)$ moderately, very or definitely agree that research helps prepare you for working in your sector.

Table 5. Opinions on various statements concerning online courses $(N=114)$.

\begin{tabular}{|c|c|c|c|c|c|c|}
\hline Statement & $\begin{array}{c}\text { Do not } \\
\text { agree at } \\
\text { all }\end{array}$ & $\begin{array}{l}\text { Slightly } \\
\text { Agree }\end{array}$ & $\begin{array}{l}\text { Moderately } \\
\text { Agree }\end{array}$ & $\begin{array}{l}\text { Very } \\
\text { much } \\
\text { Agree }\end{array}$ & $\begin{array}{l}\text { Definitely } \\
\text { Agree }\end{array}$ & $\begin{array}{l}\text { Neither } \\
\text { agree nor } \\
\text { disagree }\end{array}$ \\
\hline Online courses are less demanding & 91 & 8 & 4 & 2 & 3 & 6 \\
\hline $\begin{array}{l}\text { Online courses are harder than in person } \\
\text { courses }\end{array}$ & 17 & 24 & 23 & 11 & 17 & 22 \\
\hline $\begin{array}{l}\text { Online courses are easier than in person } \\
\text { courses }\end{array}$ & 71 & 21 & 3 & 2 & 1 & 16 \\
\hline $\begin{array}{l}\text { Online courses are equivalent to in } \\
\text { person courses }\end{array}$ & 36 & 20 & 25 & 10 & 12 & 11 \\
\hline $\begin{array}{l}\text { The quality of online courses is lower } \\
\text { than that of face-to-face ones }\end{array}$ & 36 & 27 & 13 & 16 & 11 & 11 \\
\hline $\begin{array}{l}\text { It is harder to receive help or tutelage for } \\
\text { online courses than in-person ones }\end{array}$ & 27 & 21 & 24 & 18 & 15 & 9 \\
\hline $\begin{array}{l}\text { It would be very difficult to complete } \\
\text { substantial research projects online-only }\end{array}$ & 30 & 21 & 27 & 11 & 17 & 8 \\
\hline $\begin{array}{l}\text { Research experience is very important } \\
\text { when applying to graduate school. }\end{array}$ & 1 & 13 & 25 & 29 & 37 & 9 \\
\hline $\begin{array}{l}\text { Research experience helps prepare you } \\
\text { for working in your sector. }\end{array}$ & 0 & 16 & 20 & 30 & 39 & 9 \\
\hline
\end{tabular}

Note. Respondents were given a matrix with which to indicate their opinion on a six-point scale, with a sixth point to indicate neither agreeing or disagreeing.

Respondents were also asked to rate statements concerning online students and education in general, as shown in Table 6. A large majority $(81.74 \%, \mathrm{n}=94)$ indicated that they do not agree that "online students are lazier than in-person students". The majority, $(94.78 \%, \mathrm{n}=109)$ did not agree at all with the statement that "taking your courses online means you don't take your 
education seriously." Around half $(43.48 \%, \mathrm{n}=50)$ did not agree at all to the statement that "online students are not willing to participate in extracurricular activities," while nearly the entire other half $(45.22 \%, \mathrm{n}=52)$ either slightly or moderately agreed with the statement. Responses were proportionally split for questions concerning support for online students' goals and preparedness.

Table 6. Perspectives regarding online students $(N=115)$.

\begin{tabular}{|c|c|c|c|c|c|c|}
\hline Statement & $\begin{array}{c}\text { Do not } \\
\text { agree at } \\
\text { all } \\
\end{array}$ & $\begin{array}{l}\text { Slightly } \\
\text { Agree }\end{array}$ & $\begin{array}{l}\text { Moderately } \\
\text { Agree }\end{array}$ & $\begin{array}{l}\text { Very } \\
\text { much } \\
\text { Agree } \\
\end{array}$ & $\begin{array}{l}\text { Definitely } \\
\text { Agree }\end{array}$ & $\begin{array}{l}\text { Neither } \\
\text { agree nor } \\
\text { disagree }\end{array}$ \\
\hline $\begin{array}{l}\text { Online students are not willing to } \\
\text { participate in extracurricular activities. }\end{array}$ & 50 & 27 & 25 & 8 & 1 & 4 \\
\hline $\begin{array}{l}\text { Online students are lazier than in-person } \\
\text { students. }\end{array}$ & 94 & 6 & 5 & 3 & 3 & 4 \\
\hline $\begin{array}{l}\text { Online students are more motivated than } \\
\text { in-person students. }\end{array}$ & 34 & 12 & 15 & 8 & 10 & 35 \\
\hline $\begin{array}{l}\text { Taking your courses online means you } \\
\text { don't take your education seriously. }\end{array}$ & 109 & 2 & 2 & 0 & 1 & 1 \\
\hline $\begin{array}{l}\text { There are sufficient resources to support } \\
\text { online students' goals. }\end{array}$ & 9 & 25 & 27 & 27 & 22 & 5 \\
\hline $\begin{array}{l}\text { Completing a degree online prepares you } \\
\text { sufficiently for working in your sector. }\end{array}$ & 17 & 20 & 22 & 25 & 17 & 14 \\
\hline $\begin{array}{l}\text { In person students are more motivated } \\
\text { than online students. }\end{array}$ & 52 & 15 & 10 & 9 & 2 & 27 \\
\hline
\end{tabular}

Note. Respondents were given a matrix with which to indicate their opinion on a six-point scale, with a sixth point to indicate neither agreeing or disagreeing.

\section{Qualitative Analysis}

A review of the free-response comments left by the participants identified several emerging themes that underscore the diversity not only of the online courses but also for the online students themselves. Regarding quality of online courses, participants observed that online courses are often "more frustrating" because of their modality, not the content. Regarding the diversity of the online students and their constraints and motivations, participants commented that "[online students are] left by the wayside a lot of times" and yet that "online research and learning is very possible." The additional comments all reflect the frustration online students feel in a relatively new, ever-shifting learning environment.

Many students indicated that they felt unable to summarize the difficulty of online courses because of how much it varies between courses. One such respondent said that "online environments have a lot of tech[nological] issues to work through, and as such make[s] sifting through courses difficult." Another student succinctly summarized that many of the issues with 
evaluating online courses is that "it depends," on things such as the student's "family, personal and professional situation," and another saying that it depended on "[not] the format but rather on who has set it up." One student simply replied "I want to go back to in-person classes."

The remaining comments, $75 \%(\mathrm{n}=6)$ all addressed the theme of variability in the online context and emphasized that online courses depend heavily on the instructor; online courses can be incredibly demanding simply because of the "[professors'] skill in developing online content for students." These findings suggest that although there is broad interest in online research and courses, student frustration with course quality or support specific to online students ultimately thwarts any budding interest.

\section{Discussion}

Regarding interest in and knowledge of research, findings revealed many students were highly interested in research but were unaware of opportunities. These results suggest that the online environment is not the issue, but rather the setup and quality of online education. Students are eager, motivated and intelligent; any failures that arise from a shift to online education is likely not the content or students' ability, but rather the way it is delivered. Similar studies surrounding the pandemic have found that students cite "technical issues, lack of structure, disturbances in the flow of classes, problems in clarifying doubts, [and] lack of interest and motivation to attend classes" as some primary concerns (Nambiar, 2020, p. 788). Technical issues alone can be jarring and frustrating to deal with; but these issues are often compounded by an inundation of unstructured information.

When respondents were asked to indicate their agreement to various statements concerning online education, many of the responses were mixed. Respondents' agreement was dispersed rather evenly to statements such as "online courses are harder than in person courses," but were largely in disagreement with the statement that "online courses are less demanding." As the qualitative analysis revealed, many participants commented that the demand and difficulty of an online course is typically related to the format and expectations of the professors, not the content. Explicitly defining terms such as "difficult" and "demanding", and how they differ from each other, will help disentangle students' concerns regarding content and structure.

Currently, there are no standard requirements in place for online courses, though UF supports the Quality Matters framework and provides incentives for faculty to submit their courses for review through the Center for Teaching Excellence (CTE). In addition, the CTE offers numerous 
workshops, professional communities, and support for faculty to improve their online courses. This study does not suggest implementing uniform inflexible standards, because there are a plethora of different teaching styles and learning methods; instead, quality needs to be carefully inspected per course, to ensure students are kept well-informed of course requirements, timetables, and assignments.

As for participation, online undergraduates are not aware of opportunities, thus, the quality of the opportunity is irrelevant. Mass emails or attaching research information to a homepage only serves to further inundate students in information. Reducing the amount of peripheral clutter students must navigate to find pertinent information is critical to fostering interest. Encouraging willing faculty to offer mentorship to students provides a familiar pathway to such an opportunity and makes research approachable and humanized, so that it is no longer a looming ominous term. Future research should address strategies that would effectively support and inform online students about online research opportunities. Furthermore, future studies should address the limitations of this study by recruiting more participants that identify as graduate students and faculty. Surveying faculties' willingness to facilitate research is important when discussing undergraduate research opportunities, as student research means little if there are no avenues to support such interest.

With half $(43.48 \%, n=50)$ of respondents disagreeing that "online students are not willing to participate in extracurricular activities," and another half $(45.22 \%, \mathrm{n}=52)$ either slightly or moderately agreeing with the statement, students seem conflicted on opinions about themselves. An overwhelming majority $(94.78 \%, \mathrm{n}=109)$ also disagree with misconceptions about online courses not being "serious" in terms of education. $84.71 \%(n=94)$ also rejected that online students are lazier than in-person ones. There is a deep and recognized potential of both the online format and online students, yet online students are still characterized by a lack of participation. Given the previously mentioned lack of awareness for research opportunities, the perceived fault lies not in student willingness, but student awareness.

\section{Conclusion}

In general, this study identified undergraduate online student perspectives concerning research and online courses at a large research institution. Students were found to be highly interested in online research but unaware of specific opportunities, such as USP. They expressed familiarity with the online format and held high opinions of online students, but indicated 
frustration with the fluidity with which courses are presented. With over 4000 online students at University of Florida, and more having transitioned to online due to the global health crisis, it has never been more important to understand how to support their success (UF Online Annual Report, 2021).

\section{Acknowledgements}

We would like to acknowledge the University Scholars Program of the University of Florida for funding this research study.

\section{References}

Allen, I. E., \& Seaman, J. (2007). Online nation: Five years of growth in online learning. Babson Survey Research Group \& The Sloan Consortium, 1-25.

Croxton, R. A. (2014). The role of interactivity in student satisfaction and persistence in online learning. MERLOT Journal of Online Learning and Teaching, 10(2), 314-325.

Eagan, M. K., Sharkness, J., Hurtado, S., Mosqueda, C. M., \& Chang, M. J. (2010). Engaging undergraduates in science research: Not just about faculty willingness. Research in Higher Education, 52(2), 151-177. doi: 10.1007/s11162-010-9189-9

Espinosa, L. (2011). Pipelines and pathways: Women of color in undergraduate STEM majors and the college experiences that contribute to persistence. Harvard Educational Review, 81(2), 209241. doi: 10.17763/haer.81.2.92315ww157656k3u

Herbert, M. (2007). Staying the course: A study in online student satisfaction and retention. Online Journal of Distance Learning Administration, 9(4). Retrieved from https://www.westga.edu/ distance/ojdla/winter94/herbert94.htm

Hernandez, P. R., Woodcock, A., Estrada, M., \& Schultz, P. W. (2018). Undergraduate research experiences broaden diversity in the scientific workforce. BioScience, 68(3), 204-211. https://doi.org/10.1093/biosci/bix163

Lopatto, D. (2007). Undergraduate research experiences support science career decisions and active learning. CBE-Life Sciences Education, 6(4), 297-306. https://doi.org/10.1187/cbe.07-06-0039

Nambiar, D. (2020). The impact of online learning during COVID-19: Students' and teachers' perspective. The International Journal of Indian Psychology, 8(2), 783-793. doi:10.25215/0802.094

Russell, S. H., Hancock, M. P., \& McCullough, J. (2007). The pipeline: Benefits of undergraduate research experiences. Science, 316(5824), 548-549. https://doi.org/10.1126/science.1140384

Seymour, E., Hunter, A.-B., Laursen, S. L., \& Deantoni, T. (2004). Establishing the benefits of research experiences for undergraduates in the sciences: First findings from a three-year study. Science Education, 88(4), 493-534. doi: 10.1002/sce.10131 
Swan, K. (2003). Learning effectiveness: what the research tells us. Elements of Quality Online Education, Practice and Direction, 13-45.

University of Florida (2021). UF Online Annual Report 2019-2020. Gainesville, Florida.

University of Florida. (2019). UF Online Student Experience Survey. Gainesville, Florida.

U.S. Department of Education: National Center for Education Statistics (NCES). (2018). Digest of Education Statistics. Table 311, 15.

Vieyra, M., Gilmore, J., \& Timmerman, B. (2011). Requiring research may improve retention in STEM fields for underrepresented women. Council on Undergraduate Research (CUR) Focus, 32, 1319.

Volz, K. R. (2021). The importance of undergraduate research: A gateway to possibilities. Journal of Diagnostic Medical Sonography, 37(4), 317-320. https://doi.org/10.1177/87564793211004542

Yukselturk, E., \& Inan, F. A. (2006). Examining the factors affecting student dropout in an online certificate program. Turkish Online Journal of Distance Education-TOJDE, 7(3), 76-88. 